\title{
Assessing the Possibilities of Integrating Ports into the Circular Economy
}

\author{
Alen JUGOVIĆ*, Miljen SIROTIĆ, Dražen ŽGALJIĆ, Renato OBLAK
}

\begin{abstract}
Ports are very important international hubs within transport networks where various industrial and logistical activities are performed. However, by use of the closedloop mechanism the circular economy would reduce the need for imported primary raw materials because it would treat waste as a secondary raw material. This would greatly affect the way in which ports operate because primary raw materials make up most of their cargo volume. Therefore, it is essential to evaluate the possibilities of integrating ports into the circular economy. This paper aims to use the descriptive research method to assess ports on their role in the circular economy, and based on the SWOT analysis has highlighted the key elements of circular analysis of waste streams to objectively evaluate the closed - loop mechanism. The conclusion is that due to the decline in primary raw material volumes within the circular economy, ports would therefore become centers of innovation in order to attract as many new industries as possible within their sector. The circular business model of ports would also require renewed cooperation from key actors within the port sector, the most important being the port authority, industrial clusters and academic institutions.
\end{abstract}

Keywords: Circular Economy; Circular Port; Secondary Raw Materials; Waste Management

\section{INTRODUCTION}

The twenty first century is a century of changing economic circumstances. The unprecedented side effects of the linear economy have manifested themselves on the environment as extreme depletion of primary raw materials and waste generation. In order to prevent the negative effects of the linear economy, sustainability is becoming one of the main developmental focuses in every segment of human activity. The traditional linear economy model based on the 'take, make, dispose' paradigm seeks to be replaced by the new paradigm of economic thought called the circular economy. The main driver of change towards the circular economy in the sovereign territory of the European Union is the Circular Economy Action Plan. The goal of the plan is to prevent extreme depletion of primary raw materials and waste generation. It seeks to achieve this via a closed loop mechanism within which waste would be treated as a secondary raw material. The treatment of waste as a secondary raw material would create opportunities to be reused (circularly) in a productive way that would constantly generate added value. This would extend the life cycle of (secondary) commodity flows within the supply chain and reduce the extreme depletion of primary raw materials and waste generation. Due to the fact that about $90 \%$ of the world trade is transported by sea, it can be concluded that ports are an important factor in the economy of the EU. The possible transition from a linear economy to a circular economy will cause structural changes in trade and logistics, and thus in the way how ports operate as complex industrial and logistics hubs. Therefore, assessing the possibilities of integrating ports in the circular economy is of utmost importance.

Considering the fact that there are no comprehensive documents containing guidelines for the implementation of ports in the circular economy, the aim of this paper is to present as precisely as possible the key guidelines through which the facilitation of ports into the circular economy would be anticipated. This was achieved through the analysis of ports based on two aspects: (1) the role of ports in the circular economy as hubs for primary raw material streams and waste streams and (2) waste streams are analyzed in industrial port clusters that could be used as secondary commodity flows. The first aspect has been clarified in such a way that the aforementioned implementation requires a synergistic approach by different actors within the port sector across seven key areas. Within the second aspect, a circularity analysis of various types of waste was performed, highlighting the most important ones, such as construction, steel, electronic and plastic waste. Both aspects should be monitored on a micro, meso and macro level.

There are a number of challenges that ports face if they are to be integrated into the circular economy. The closed loop mechanism would reduce the amount of negative externalities because waste would be treated as a secondary raw material and the use of primary raw materials would be reduced. A decrease in the use of primary raw materials would result in a decrease in the amount of commodity flows in ports because primary raw materials make up the majority of cargo volumes in ports. In order to better adapt to such change, ports should develop as much synergy as possible with existing industries within their sectors, and should develop various marketing models to attract new industries. Their initial advantage is that they have an exceptionally good connection with the waterfront and the hinterland and this opens for new industries a wide range of business opportunities within the circular economy.

\section{DRIVERS OF CHANGE TOWARDS A MORE SUSTAINABLE ECONOMIC MODEL}

The effects of constant economic development, industrialization and urbanization have begun to have a negative impact on society through the generation of large quantities of waste. Managing the rapid growth of quantities of solid and hazardous wastes is becoming ever so complex and problematic for contemporary governments. Inappropriate handling of waste leads to threats to the environment, such as greenhouse gas emissions, land degradation, water and resource pollution [1]. It has been identified that waste disposal and primary raw material depletion are two of the most urgent problems facing humanity. These two problems create the consequences that current supply chains face significant material losses between the excavation phase and the 
production phase. Based on Sustainable Europe Research Institute (SERI) data, the Organization for Economic Co operation and Development (OECD) member states have consumed on an annual basis more than 21 billion tons of raw materials that were not physically incorporated into the final product [2].

Examples of such unutilized raw materials within the economic system are overburden materials and parting materials during mining; bycatch from fishing; agricultural and harvesting losses, as well as losses suffered from soil excavation and dredged materials from construction activities. The chances of recycling most of the aforementioned raw materials at the end of their functional life are quite low relative to primary production rates. Based on data from the Ellen MacArthur Foundation, it has been estimated that around 65 billion tons of raw materials entered the global economic system in 2010. It has also been forecast that by 2020 raw materials will grow by 82 billion tons. The European Union has generated 2.7 billion tons of waste in 2010. Of that amount, only $40 \%$ was reused, recycled, composted or recovered [3]. The inadequate management of large quantities of waste that has the potential to be reintegrated into the supply chain results in the loss of waste itself as a secondary raw material and as a source of energy.

Waste management is of particular concern for the European Union because it is highly dependent on imported raw materials. Trade in imported raw materials is extremely important for the sustainability of European countries and their economies. The import / export values are depicted in Fig. 1. It can be concluded that the European Union has been experiencing a trade deficit in imported raw materials since 2002. Trade dropped in 2009 because of the financial crisis of 2008, but then it quickly recovered. The highest rate of imports was recorded in 2011 at a value of $€ 85$ billion and the highest rate of exports was recorded in 2012 at a value of $€ 48$ billion. After the peaks of 2011 and 2012, there has been a steady decline until 2016 when imports were at the value of $€ 68$ billion and exports at the value of $€ 42$ billion.

Based on the data presented in Fig. 1, it can be concluded that the EU must increase the rate of waste recycling if it seeks to reduce its dependence on imported primary raw materials. The EU managed to recycle $55 \%$ of all types of waste in 2016; compared to 2010, when the total amount of recycled waste was $40 \%$ [3].

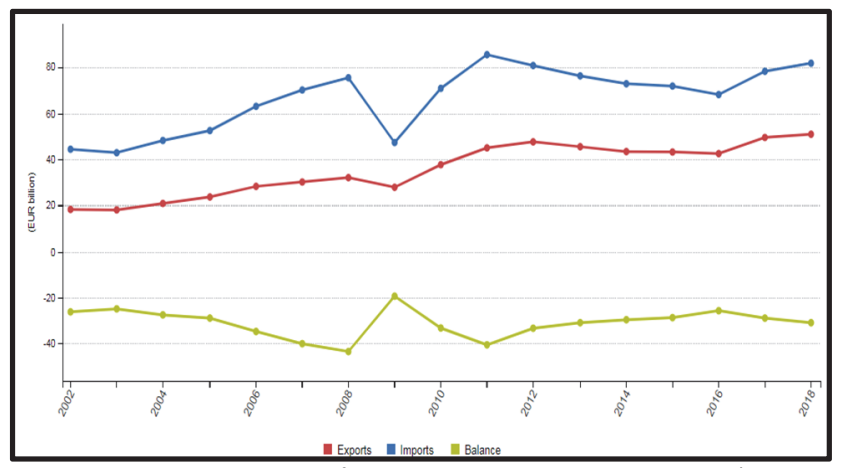

Figure 1 Trade balance of raw materials in the European Union [4]

In 2016, the recycling rate for construction and demolition waste was $89 \%$. The recycling rate of packaging waste reached $67 \%$ in 2016 , compared to $64 \%$ in 2010, while the rate of plastic packaging was over $42 \%$ in 2016 , compared to $24 \%$ in 2005 . In 2017 , municipal waste recycling rates were $46 \%$ compared to $35 \%$ in 2007 . Electrical and electronic equipment waste, such as computers, televisions, refrigerators and cell phones, which include valuable e - waste materials in the European Union, reached $41 \%$, compared to $28 \%$ in 2010 . The overview of recycling rates of different waste streams is depicted in Fig. 2.

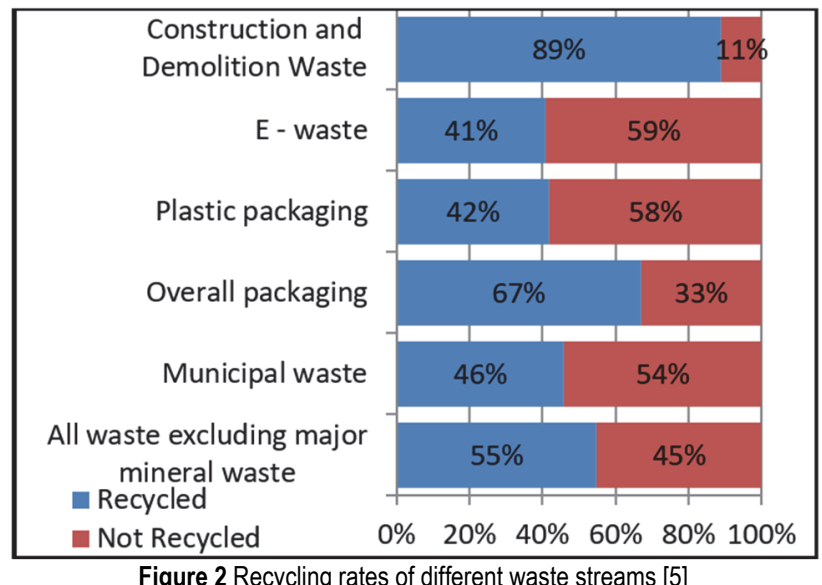

In spite of these high recycling rates, on average only $12 \%$ of secondary raw materials used in the EU in 2016 came from recycled products and recovered materials-thus poorly saving extraction of primary raw materials [6]. This indicator, called circular material use rate, measured the contribution of recycled materials to overall demand [7]. The indicator is lower than recycling rates, which measure the share of waste which is recycled, because some types of materials cannot be recycled, e.g. fossil fuels or biomass that are incinerated to produce energy. It is hard to pinpoint direct links between raw material use and waste generation regarding quantification with current indicators. The reason for this is because of the difference in calibration methods for waste generation and resource use, and a lack of long-term time-series data.

The EU seeks to change its dependence on imported raw materials and how they are used in production processes to ensure sustainable economic growth and social cohesion. It seeks to achieve this by reducing the impacts of waste on the environment and human health by improving the utilization of its own sources of primary raw materials. The long term goal is to turn Europe into a recycling society, by avoiding waste generation and by promoting the use of waste as a secondary raw material whenever possible. The aim is to achieve much higher levels of recycling and to minimize the extraction of additional primary raw materials. Proper waste management is a key element in ensuring raw material efficiency and the sustainable growth of European economies. The basic concepts and definitions regarding waste definition, waste management, waste recycling and waste recovery are stated within the EU Waste Directive 2008/98/EC. The directive stipulates that waste legislation and policy of the EU member states shall apply as a priority order in the following waste management hierarchy: [8] 1. Prevention: Measures taken before a substance, material or product becomes waste, which reduce: 
a. The quantities of waste, including reduction in reuse of the product or extending its life;

b. Adverse effects of waste on the environment and human health;

c. The content of harmful substances in materials and products.

2. Preparation for reuse: Recovery operations, such as inspection, cleaning or repair, that prepare products or parts of products that have become waste so that they can be reused without further pre-treatment.

3. Recycling: Any recovery operation by which waste materials are processed into products, materials or substances for original or other purposes.

4. Other recovery processes: E.g. energy recovery;

5. Disposal: Any non-recoverable operation, even when the operation has a secondary effect on the recovery of the substance or energy.
In order to further the facilitation of the use of waste as a secondary raw material, the European Union has devised the Circular Economy Action Plan. The main objective of the plan is to promote a systematic approach of life-cycle thinking in waste management in order to reduce environmental impacts and enhance a more efficient raw material use across entire value chains [9]. The insurance of raw material efficiency through recycling and reuse has been identified for the next four priority sectors: production, consumption, waste management and secondary raw resources. The wastes that must be recycled and reused as secondary raw materials are: biomass and bio based products, plastics, food waste, critical raw materials and construction and demolition. Tab. 1 shows the key objectives and key actions of the Circular Economy Action Plan that have to be reached in order to facilitate a more sustainable form of economic growth.

\begin{tabular}{|c|c|c|}
\hline \multirow[b]{2}{*}{ PRODUCTION } & Objectives & $\begin{array}{l}\text { - Provide Incentives to boost circular product design } \\
\text { - Innovative and efficient production processes }\end{array}$ \\
\hline & Key actions & $\begin{array}{l}\text { - Durability, reparability and recyclability of products - Ecodesign Directive, Extended Producer Responsibility } \\
\text { - Best practices for waste management and resource efficiency in industrial sectors - BREFs } \\
\text { - Industrial symbiosis, remanufacturing } \\
\text { - Coherent policy framework for products, tools for SMEs }\end{array}$ \\
\hline \multirow[b]{2}{*}{ CONSUMPTION } & Objectives & $\begin{array}{ll}\text { - } & \text { Repair and reuse of products } \\
\text { - } & \text { Reliable information to consumers }\end{array}$ \\
\hline & Key actions & $\begin{array}{l}\text { - Better labelling: EU Eco - label, Environmental Footprint labelling } \\
\text { - New forms of consumption - collaborative economy, digital platforms } \\
\text { - Guarantees and action on false green claims } \\
\text { - Independent testing programme to assess possible planned obsolesence } \\
\text { - Circular Economy criteria in Green Public Procurement }\end{array}$ \\
\hline \multirow[b]{2}{*}{$\begin{array}{l}\text { WASTE } \\
\text { MANAGEMENT }\end{array}$} & Objectives & $\begin{array}{l}\text { - Improve waste management in line with the EU waste hierarchy } \\
\text { - Adress existing implementation gaps } \\
\text { - Provide long - term vision and targets to guide investments }\end{array}$ \\
\hline & Key actions & $\begin{array}{l}\text { - Revised EU targets for recycling } 65 \% \text { of municipal waste and } 75 \% \text { of packaging waste by } 2030 \text {. } \\
\text { - New binding target to reduce landfill to a maximum of } 10 \% \text { of total waste by } 2030 \text {. } \\
\text { - Improve waste management, new investments in recycling capacity, avoid overcapacity in incineration and } \\
\text { mechanical - biological treatment } \\
\text { - Ensure coherence between waste investments under EU Cohesion Policy and the waste hierarchy }\end{array}$ \\
\hline \multirow{2}{*}{$\begin{array}{l}\text { SECONDARY } \\
\text { RAW } \\
\text { MATERIALS }\end{array}$} & Objectives & $\begin{array}{l}\text { - Increase the use of secondary raw materials } \\
\text { - Increase the use of recycled nutrients and water } \\
\text { - Safely managed chemicals } \\
\text { - Improve knowledge of material flows }\end{array}$ \\
\hline & Key actions & $\begin{array}{l}\text { - EU regulation on fertilisers } \\
\text { - Legislative proposal on min. requirements for reused water } \\
\text { - Quality standards for secondary raw materials } \\
\text { - Analysis on the interface between chemicals, product, and waste legislation } \\
\text { - EU-electronic system for cross-border transfers of waste }\end{array}$ \\
\hline
\end{tabular}

\section{COMPARATIVE ANALYSIS BETWEEN THE LINEAR AND THE CIRCULAR ECONOMY}

The linear economy is the dominant economic form of conduct in the contemporary world. It is a historical product of unequal distribution of wealth across geographical regions. The aforementioned unequal distribution of wealth was manifested through the creation of the Western society as the richest and most developed geographical region, which collected primary raw materials from neighboring regions. In this way, the industrial states of the West experienced an abundance of primary raw materials and energy. The enormous abundance of allocated primary raw materials created conditions for their inexpensive use via human labor for the enterprises' manufacturing facilities. This resulted in the adoption of business models that neglected the environmental aspect of conducting business while relying on the vast amounts of collected primary raw materials. Considering the aspect of competition in the free market, this has resulted in an even more irresponsible exploitation of primary raw materials and energy in order to achieve a competitive edge. The natural consequences of inexpensive primary raw materials and expensive labor were the usual neglect of recycling, reuse and putting great emphasis on waste [2]. The linear economy was further perpetuated through the elements of its own system structure. It has achieved this through fiscal, accounting and regulatory standards by failing to develop an external cost recovery mechanism; which would result in manufacturers considering the external costs of their manufacturing facilities. In addition, the system is 
inherently inert because formal product approval procedures favor existing practices rather than radical changes and the reinvention of basic principles [2]. Fig. 3 depicts the three phases of the linear economy and the steps that occur within them.

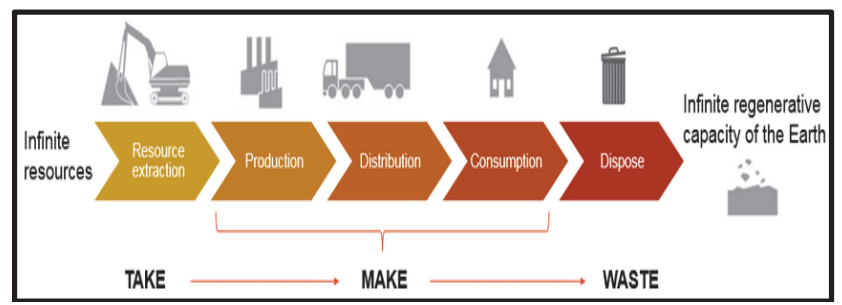

Figure 3 The three phases of the linear economy [13]

It can be seen from Fig. 1 that the linear economy consists of three phases. Each phase has one or more separate actions. The first phase, named "take", contains the primary raw material extraction activity. During this phase, the company collects the necessary primary raw materials to help it conduct its business. After that, the second phase, called "make" begins. This phase consists of three actions: production, distribution, consumption. In this phase, the company manufactures goods by using the primary raw materials it extracted. After the goods are manufactured, they are distributed within the supply chain to end-users who buy them with the aim to consume them. The third and the last phase called "waste" is composed of only one action; dispose. After the end-user has made full use of the product's life cycle value, he discards it, thus creating waste. It can be concluded that the production method of the linear economy is unsustainable as it generates large quantities of waste.

The problem with the linear economy is that it is based on the incorrect assumption that primary raw materials are inexhaustible and that planet Earth has room for unlimited waste disposal. In the long run, the linear economy significantly increases the costs that will be encountered in solving various environmental problems, unemployment and lack of resources. At first glance, the system seems simple, efficient and without setbacks; but in reality, it is reaching a tipping point. The byproducts of the linear economy model can be mitigated or solved by a new emerging economic concept, called the circular economy concept. The circular economy concept is rooted in a variety of schools of thought that aim to further develop the aspect of sustainability in economics. There are five schools of thought that are accepted as the basis for the circular economy concept:[14]

1. The performance economy: The main focus of this type of economy is on selling performance (services) instead of goods, internalizing all costs (closing the loops). It believes this will we achieved by combining system design, technical and commercial innovation-mainly within regional economies, developing business models of remarketing goods (reuse), and extending the product life of goods and components (eg through remanufacturing and upgrading) to create local jobs, increase "resource husbandry" and prevent waste.

2. Natural Capitalism:This type of economy imagines a new industrial revolution, where environmental and business interests overlap, and companies can simultaneously improve profits, help solve environmental problems and feel positive about their impacts. Natural capital encompasses both natural resources and ecological systems, providing vital life support services to all living things.

3. Industrial Ecology:The main goals of this type of economy is to help businesses in their understanding of how they use key resources, track material, energy and water flows, and how to account for a product through its life-cycle. It aims to change resource use from being implicit to explicit, from the beginning of the cycle to the end of use.

4. Blue Economy:This type of economy bases its solutions on physics, using nature's systems of cascading nutrients, matter and energy as the ideal model. In the blue economy, waste does not exist, and any by-product can be the source for a new product.

5. Cradle to Cradle:This type of economy stipulates the importance of treating materials as biological or technical nutrients and extending the "use period" for all materials. It encourages a systems-thinking approach, reframing design to be regenerative, and constantly progressing from being "less bad" to doing "more good".

Table 2 Various definitions of the circular economy concept - current research [15-20]

\begin{tabular}{|c|c|c|}
\hline Ordinal Number & Author(s) & Definition \\
\hline 1 & Preston (2012) & $\begin{array}{l}\text { Circular economy is an approach that would transform the function of resources in the economy. Waste from } \\
\text { factories would become a valuable input to another process, and products could be repaired, reused, or upgraded } \\
\text { instead of thrown away. }\end{array}$ \\
\hline 2 & Bastein et al. (2013) & $\begin{array}{l}\text { The circular economy transition is an essential condition for a resilient industrial system that facilitates new } \\
\text { kinds of economic activity, strengthens competitiveness, and generates employment }\end{array}$ \\
\hline 3 & Mitchell (2015) & $\begin{array}{l}\text { A circular economy is an alternative to a traditional linear economy (make, use, dispose) in which we keep } \\
\text { resources in use for as long as possible, extracting the maximum value from them while in use, then recovering } \\
\text { and reusing products and materials }\end{array}$ \\
\hline 4 & $\begin{array}{c}\text { European } \\
\text { Commission }(2015)\end{array}$ & $\begin{array}{l}\text { The circular economy is an economy "where the value of products, materials, and resources is maintained in the } \\
\text { economy for as long as possible, and the generation of waste minimized." The transition to a more circular } \\
\text { economy would make "an essential contribution to the EU's efforts to develop a sustainable, low-carbon, } \\
\text { resource-efficient, and competitive economy" }\end{array}$ \\
\hline 5 & Sauvé et al. (2016) & $\begin{array}{l}\text { Production and consumption of goods through closed-loop material flows that internalize environmental } \\
\text { externalities linked to virgin resource extraction and the generation of waste (including pollution) }\end{array}$ \\
\hline 6 & Mao et al. (2018) & $\begin{array}{l}\text { A circular economy is an economic form with material circular flow as its core, and it attempts to reduce the } \\
\text { influences of human activity on the natural environment system via the flow of closed material in the human } \\
\text { socio-economic system, based on phased and efficient utilization of the energy flowing into the human socio- } \\
\text { economic system }\end{array}$ \\
\hline
\end{tabular}


The circular economy is an amalgamation of the aforementioned five schools of thought. Owing to the fact that the circular economy is an emerging concept of enterprise management, the consensus of an adequate and comprehensive definition has not yet been achieved. However, there is much agreement on the elements of the circular economy concept in the scientific research literature. Tab. 2 incorporates various definitions of the circular economy concept from 2012 towards 2018.

The selected definitions in Tab. 2 provide insight into the key features of the circular economy. All definitions point to the fact that the circular economy is an economic model where raw materials, production processes and products are used cyclically within the stages of production, distribution, exchange and consumption while respecting the environmental criterion. Preston's definition indicates that waste from one production system to another would be treated as a raw material. Therefore it can be concluded that the circular economy treats waste as a secondary raw material. This is in line with Bastein's definition because the emergence of secondary raw materials would create new economic activities and increase the number of workforce to perform these activities. Mitchell's definition is the continuation of Bastein's because it highlights the difference between the circular economy and the linear economy by highlighting key circular activities: increasing product life cycle, maximizing value extraction, recycling and reuse. The next definition in the series is from the European Commission. This definition is of key importance because it reflects the basic objectives of the Circular Economy Action Plan, such as reducing imported primary raw materials and increasing the focus on treating waste as a secondary raw material. Subsequently, Sauvé's definition stands out because it mentions the closed-loop mechanism that is the fundamental feature of the circular economy. By the closed-loop mechanism the circular economy seeks to achieve cyclicality of primary and secondary raw materials to reduce externalities. The last definition in the series is from Mao. Its key point is that it holistically encompasses all other definitions. It does so by further emphasizing the closed-loop mechanism by mentioning energy efficiency through the use of renewable energy in all segments of human activity.
Therefore, it can be concluded that the fundamental difference between the linear economy and the circular economy stands out in the closed-loop mechanism which the circular economy possesses as opposed to the linear economy. Through this type of mechanism, recovered products, parts and materials are used for reuse or for the creation of new products. This mechanism allows the circular economy to control the amount of raw material consumption and waste discharges into the environment. It allows the creation of conditions within which raw materials circulate within the production and consumption system. The goal of the circular economy is to optimize the use of primary raw materials and reduce waste pollution. It seeks to achieve the stated aim by reusing waste as a secondary raw material in each circular step, as far as possible and desirable. Fig. 4 shows the difference between the linear economy and the circular economy.

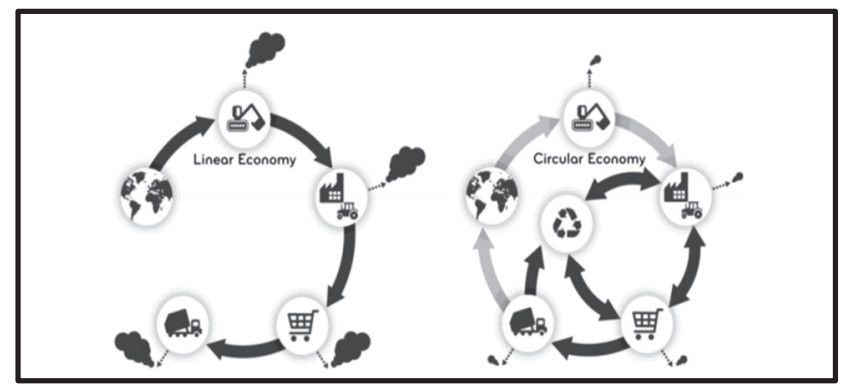

Figure 4 The difference between the linear and the circular economy [19]

The circular economy concept is increasingly attracting attention from the private and public sector because of financial, social and environmental reasons [21]. It is accepted that the concept of the circular economy is a sustainable development strategy that needs to find solutions to address the negative impacts of waste disposal on the environment and the lack of basic raw materials. The importance of the circular economy concept is that it is a model for overcoming the current linear economy model. It aims at increasing the efficiency of raw material use, especially when it comes to industrial waste, thereby achieving harmony between the economy, the environment and society [22].

Table 3 Circular Economy SWOT analysis

\begin{tabular}{|c|c|}
\hline STRENGTHS & WEAKNESSES \\
\hline $\begin{array}{l}\text { - Stable economic growth. } \\
\text { - The closed loop enables reverse material logistics, which } \\
\text { represents a potential competitive advantage. } \\
\text { - } \quad \text { Removal of waste from supply chains represents an opportunity } \\
\text { to reduce system costs. } \\
\text { - Treatment of waste as a secondary raw material reduces } \\
\text { dependence on primary raw materials. } \\
\text { Due to the closed loop mechanism, the economy is less exposed } \\
\text { to fluctuations in commodity prices. }\end{array}$ & $\begin{array}{l}\text { - The circular economy still requires amalgamation of the entire product life } \\
\text { cycle. } \\
\text { There are no specific guidelines for how to implement the circular economy } \\
\text { in individual areas of human activity. (eg The martime industry) } \\
\text { There are no internationally recognized standards or institutions regulating } \\
\text { the circular economy. } \\
\text { There is no legislative basis for regulating business within the circular } \\
\text { economy. } \\
\text { Waste is not perceived as a secondary raw material. }\end{array}$ \\
\hline OPPORTUNITIES & \\
\hline 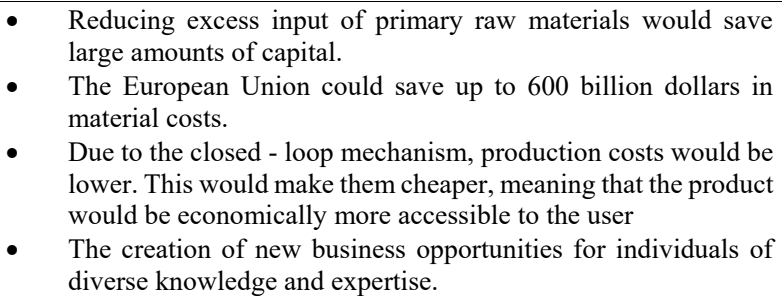 & $\begin{array}{l}\text { - If companies can control the entire product life cycle, they can easily } \\
\text { subsidize various activities, which can result in high product prices. } \\
\text { Full product life cycle management and strong collaboration can create cartel } \\
\text { structures. } \\
\text { - Gradual disruptions to the financial system can cause negative outcomes for } \\
\text { an interdependent individual sector due to a complex and interconnected } \\
\text { sector. }\end{array}$ \\
\hline
\end{tabular}


Waste elimination from supply chains would be beneficial because it would result in the reduction of systemic and direct material costs, as well as raw material dependency. Therefore, the circular economy possesses the potential to benefit operational and strategic enterprises because it would lower the input rates of scarce primary raw materials, which would result in saving large sums of capital. The Ellen MacArthur Foundation stipulates that the European Union would save up from 400 to 600 billion dollars worth of material costs yearly, mainly in the automobile and machinery sectors [3]. Considering this point of view, the closed-loop mechanism would enable the economy to be more resilient on price fluctuations of primary raw materials and the flattened cost curve ultimately results in a more efficient use of primary raw materials in terms of both value and volume. Despite the benefits and opportunities that the circular economy is fostering, it is also important to note the challenges that may arise during its realization. A more comprehensive view of the circular economy is presented through the SWOT analysis in Tab. 3. The circular economy can be considered as a certain upcoming phase of the capitalist socio - economic system, which tries to achieve as much as possible through the closed loop mechanism the flow of primary and secondary materials in every segment of human activity. Its main objective is to separate the constant economic growth from the overexploitation of raw materials while taking into account environmental conservation. It can be considered as the diametrical opposite of the linear economy because the linear economy does not sufficiently take into account the environmental and social consequences of achieving economic goals. The fundamental differences between the linear and circular economy are shown in Tab. 4.

Table 4 Fundamental differences between the linear and the circular economy

\begin{tabular}{|c|c|}
\hline The linear model & The circular model \\
\hline $\begin{array}{l}\text { It is irresponsible for the use of raw materials. (Creates wealth regardless of } \\
\text { the environment). }\end{array}$ & $\begin{array}{l}\text { It is responsible for the use of raw materials. (Creates wealth by considering } \\
\text { the environment) }\end{array}$ \\
\hline $\begin{array}{l}\text { Treats waste as an economically useless entity. (Waste is a structural } \\
\text { component of the linear economy). }\end{array}$ & Treats waste as a secondary raw material. \\
\hline $\begin{array}{l}\text { It is based on the take, make, dispose paradigm by which resources are } \\
\text { excavated, produced, consumed, and eventually discarded as waste. }\end{array}$ & $\begin{array}{l}\text { It is based on the paradigm of the closed-lop mechanism through which it } \\
\text { seeks to hold raw materials in circulation as long as possible. }\end{array}$ \\
\hline The model is based on a single use of the product. & $\begin{array}{l}\text { The model is based on reusable products (through repairs, recycling, reuse, } \\
\text { etc.) }\end{array}$ \\
\hline The model ignores the concept of product life cycle. & $\begin{array}{l}\text { The model takes into account the concept of product life cycle and seeks to } \\
\text { extend it. }\end{array}$ \\
\hline $\begin{array}{l}\text { It does not place emphasis on renewable energy sources during production } \\
\text { processes. }\end{array}$ & It emphasizes renewable energy sources during production processes. \\
\hline Considers recycling as a side activity through which waste is reduced. & $\begin{array}{l}\text { It considers recycling as a key component of the system through which it } \\
\text { eliminates waste by treating it as a secondary raw material. }\end{array}$ \\
\hline
\end{tabular}

\section{THE ROLE OF PORTS IN THE CIRCULAR ECONOMY- OPPORTUNITIES AND CHALLENGES}

Maritime transport remains the backbone of globalized trade and the manufacturing supply chain, as more than four fifths of world merchandise trade by volume is carried out by sea [23]. The key nodal points in between maritime transport and land transport are ports. Ports can be defined as land areas with maritime and hinterland accesses that have developed into a logistics and industrial center, playing an important role in global industrial and logistics networks [24]. They are facing sustainability challenges due to effects of economic structural change and globalization. As a result, they are forced to rethink their strategies and operations in an environment of increased scrutiny of action to reduce externalities. They are considered as crucial actors in the global movement of commodity flows, as well as the gates to and from their markets because they link international supply chains and are critical to the global economy and the trading system. Ports have the potential to strengthen the circular economy globally and locally because they are key links within the supply chain. After the economic crisis of 2008, the sustainable long-term development of ports and port areas has been focused on the first two principles, with the addition of a third principle: $[25,26]$

1. The synergy principle between different actors/systems, in particular, the sociocultural and economic system.

2. The creativity and innovation principle.

3. The circularization principle.
If a port is to become sustainable, it must be developed through adherence to these three principles and it can be considered sustainable when it has achieved a long term and effective balance of social, economic and environmental values. A sustainable sea port is a sea port where social, economic and environmental values are balanced in a long term and efficient way. Sustainable sea ports would realize the closed-loop mechanism regarding material and energy flows in circular activities between various stakeholders and actors. Considering that they serve as gateways to global trade and they are facilities where value added services on all kinds of resources are provided, it can be concluded that they can also perform circular activities regarding waste reuse as secondary raw materials. If sea ports are considered as the "crossingpoints" for waste and primary raw materials, then it makes sense why they are ideal for developing the circular economy [27]. The execution of circular economic activities in ports is likely to be more profitable because of industrial parks, clustering activities and megacities in the proximity of ports [28]. Therefore, it is important to analyze ports with regard to two aspects:

1. Define the role of sea ports in the circular economy as hubs for waste streams and material streams.

2. Analyse waste streams in sea port industrial clusters that could be used as secondary material streams in order to achieve and facilitate the closed-loop mechanism.

In the circular economy, waste streams in the port sector would be used as secondary raw materials in all parts of the supply chain, thus shifting the focus on closing the loop through reduction, reuse and recycling through an 
institutionalized and systemic way [29, 30]. This requires a complete restructuring of industries, their production processes and consumption activities [31, 32]. The integration of the port sector in the circular economy would be addressed through next key areas: [33-35]

1. Minimize input usage of primary raw materials and eliminate waste and pollution.

2. Maximize the usage of renewable sources of energy and secondary raw materials.

3. Maximize the creation of value of secondary raw resources at each stage of the closed-loop mechanism.

4. Enable bio-based resource flow management and closed-loop recovery of non-renewable resources.

5. Studying feedback loops within the sea port system to optimize the entire conglomerate of the industrial production system within the sea port system.

6. Establish a mutually beneficial relationship between companies within the circular supply chain.
7. Maximizing the usage value of products through sharing them among users and prolonging their life through reuse, maintenance and repair.

Such integration requires a synergistic approach from different stakeholders within the port sector. This would be achieved through a combination of economic, logistical and industrial activities with the cultural heritage of the port and the creativity of the wider community [28]. The result would be a dynamic, complex and sustainable system. Each port would have a different approach for solving the emerging circular waste management challenge because of the different types of waste generated by the industrial cluster located within the port sector. A circular analysis of waste streams from various industries that could be used in port industrial clusters as secondary raw material flows through a closed loop mechanism as stated in Tab. 5.

Table 5 Circularity analysis of waste streams [36-40]

\begin{tabular}{|c|c|}
\hline Type of Waste & Circularity Analysis \\
\hline Construction Waste & $\begin{array}{l}\text { Construction waste is an endless source of secondary raw materials for various purposes if it is effectively recycled and sorted. } \\
\text { Construction waste includes concrete, bricks, gypsum, wood, glass, metals, plastics, and solvents, asbestos and excavated soil. } \\
\text { The European Union has a construction waste recycling rate of approximately } 89 \% \text {. }\end{array}$ \\
\hline Steel Scrap & $\begin{array}{l}\text { In } 2015 \text {, recycling of steel scrap amounted to around } 550 \text { million tons globally. This is approximately one - third of total steel } \\
\text { production. However, recycling rates are higher than would be expected because the life cycle of steel is very long. Some countries } \\
\text { produce a high proportion of recycled steel, such as the US (approx 70\%) and the EU (approx 50\%). Important recyclables include } \\
\text { ships and coastal installations. Both require specific facilities for removal, separation and decomposition. }\end{array}$ \\
\hline Wastewater & $\begin{array}{l}\text { Wastewater contains phosphate. Phosphate is excavated and used as fertilizer. Phosphate is often not recovered from wastewater } \\
\text { or sewage. There are emerging initiatives to separate phosphate from wastewater (secondary phosphate). }\end{array}$ \\
\hline Tires & $\begin{array}{l}\text { Car tires are closely linked to the concept of recycling. About } 1 \text { billion tires (approx } 13.5 \text { million tons) are removed annually from } \\
\text { vehicles. Tire recycling rates in the European Union are generally low (less than } 40 \% \text { ). Tires contain a significant amount of } \\
\text { valuable high quality carbon black. Contemporary innovative processes allow the carbon black to be recovered from tires, thereby } \\
\text { improving the circularity of tires in the supply chain. }\end{array}$ \\
\hline Electronic Waste & $\begin{array}{l}\text { Almost } 42 \text { million tons of e-waste are generated globally. That number is expected to increase to } 50 \text { million tons in the future. } \\
\text { Consumer electronics recycling rates are low (less than } 40 \% \text { ). European Union exports e-waste to low-income countries. However, } \\
\text { initiatives for e-waste recycling are emerging. }\end{array}$ \\
\hline Plastic Waste & $\begin{array}{l}\text { Global plastics production is over } 300 \text { million tons. Plastics are mainly used in packaging (approx } 40 \% \text { ) and construction (approx } \\
20 \% \text { ). Plastics recycling is an established industry, especially for waste from factories (which is relatively clean, of limited variety } \\
\text { and collected in large quantities) and has a considerable recycling rate. About } 25 \text { million tons of plastic waste has been generated } \\
\text { in the European Union after use. This amounts to approximately } 20-30 \mathrm{~kg} \text { of plastic waste per person per year. }\end{array}$ \\
\hline Textile Waste & $\begin{array}{l}\text { Global textile production is around } 90 \text { million tons. Most textiles are based on chemicals, while one - third are based on natural } \\
\text { resources such as cotton. Advances in textile sorting technology based on the fiber composition of fabric make recycling } \\
\text { sustainable and will eventually enable the closed-loop textile industry. Textile recycling is of global nature and developing } \\
\text { countries have a higher recycling rate than developed countries. }\end{array}$ \\
\hline Paper Waste & $\begin{array}{l}\text { Total paper and cardboard production is approximately } 400 \text { million tons. The current recycling rate in most EU countries is } 55 \% \\
\text { to } 60 \% \text {. The quantities of imported and exported paper pulp are significant. For example, the US exports about } 1.2 \text { million TEU } \\
\text { of waste paper per year, making it their largest export commodity. Most paper waste is returned to the US in form of packaging. } \\
\text { Paper recycling rates can increase, especially in emerging economies. }\end{array}$ \\
\hline Glass Waste & $\begin{array}{l}\text { The global glass market consists of over } 100 \text { million tons of glass annually. It is divided into flat glass for construction and } \\
\text { automobile industry and container glass for food and beverages. Glass has a high recycling rate (approx } 70 \% \text { ) and can be recycled } \\
\text { multiple times without significant loss of quality. }\end{array}$ \\
\hline
\end{tabular}

The synergy and cooperation between ports and their industrial clusters within the circular economy supply chains should be studied in greater depth on three levels:[41, 32]

1. Micro-level: Focuses on improving the environmental performance of an individual enterprise by reducing resource consumption, reducing pollution, by designing more environmentally friendly products. An example for the seaport sector would be the reuse of waste as a secondary raw material within one company within a port industrial cluster.

2. Meso-level: Focuses on eco-industrial networks aiming to improve regional production systems and environmental protection, energy cascade, product exchange, waste recycling and local infrastructure sharing. Typical practice at this level is the development of eco- industrial parks. An example for the port sector would be an industrial symbiosis of two or more companies within a port industrial cluster.

3. Macro-level: Focuses on municipalities, cities, regions or provinces to develop a sustainable production as well as a sustainable consumption system. An example for the port sector would be the creation of an inter-regional exchange network for transporting secondary raw materials between two or more port industrial clusters.

A shift from the traditional linear economy supply chain towards the new circular economy supply chain poses several challenges for ports. Changing the structure of supply chains from linear towards circular would reduce the flow of primary raw materials through ports because the system would close or narrow down due to the closedloop mechanism. The decrease in demand for primary raw 
materials would lead to the decrease in primary bulk materials that represent a majority of the volume of cargo that is manipulated in most ports.Therefore, it can be concluded that traffic within the port would be diminished. This also creates the possibility of a conflict of interest between the port authority and the circular economy policy makers. This is because port authorities pursue a mixture of economic objectives such as financial sustainability of the port, maximization of added value and their most important objective, maximization of port throughput [42]. The challenge would be to reach enough critical mass of secondary raw resources in the port circular economy business model for certain waste to obtain economic profitability.

The closed loop mechanism would accelerate the shift from global supply chains towards regional supply chains due to increased recycling rates and raw materials efficiency. This would affect the competitiveness of ports because the presence of traditional large fossil fuel based industrial complexes becomes less relevant [36]. The shift from the linear supply chains towards the circular supply chains would result in formation of new development pathways. However, industrial cluster synergy would still be of great importance for the port sector. This means that ports that already possess industrial cluster synergy can gain an early competitive advantage by attracting new circular economy activities in lieu of ports that do not possess industrial cluster synergy. Although ports compete with other ports, they would also compete with alternative industrial clusters that are not encompassed within their sector. In this case scenario, ports would also gain an early competitive edge because of their high quality connectivity (the waterfront and the hinterland), which would enable them an economically more acceptable access to secondary raw resources within the market of circular supply chains. This would have the potential for ports becoming sites where there is a concentration of demand for circular products such as energy, fuel and raw materials.

There are no comprehensive documents that have specific guidelines for the integration of ports in the circular economy on a legislative level. The documents that are closest for establishing a legal framework for the integration of ports towards a circular economy are Directive 2008/98/EC on the prevention or reduction of the adverse effects of waste production and management and Directive 2000/59/EC on port reception facilities for ship generated waste and cargo residues $[12,43]$. Ports would also face next challenges: $[44,45]$

1. Knowledge of the contribution of a particular economic activity to the environment.

2. Training the workforce with adequate skills.

3. Lack of experts and professionals to implement the circular economy into the port sector

4. Raising awareness and increasing recycling capacity in enterprises.

5. Changing consumer behaviour.

6. Changing the relationship between consumer and producer liability regimes.

7. Pricing goods and services to reflect the full costs and set policies that promote a circular economy.

8. Lack of space in the sea port sector for the installation of new recycling facilities (industrial clusters would need to be expanded).
9. Overall negative public opinion on waste makes it difficult to install recycling facilities within the seaport sector.

10. The development and implementation of circular economy strategies requires renewed cooperation between the various actors within the sea port sector (port management body, harbour master's office, freight forwarding companies, industry clusters, academic institutions) and even cooperation with citizens' associations because the port is an integral part of the city. 11. Sea ports handle a huge volume of nonrenewable (linear) resources. The trend toward circularity would most likely lead to a decline of these volumes, therefore putting into question the economic feasibility of sea port business.

\section{CONCLUSION}

The negative side effects of the linear economy such as extreme primary raw material depletion and waste generation have given rise to the idea of sustainable raw material management on a world-wide level. The leading government authorities seek to change these side-effects by increasing focus on recycling and reuse in order to achieve better raw material efficiency. The economic model that provides possibilities for recycling and reuse is called the circular economy. This model provides new opportunities for economic growth because it enables the circulation of waste as a secondary raw material within supply chains. By enabling this way of economic conduct, the extreme extraction of primary resources would be lower, as well as waste generation, because waste would be used in production processes, instead of being discarded.

The European Union has developed the Circular Economy Action Plan by which it aims to implement the circular economy on its sovereign territory. The restructuring of the European Union's economy from the traditional linear model towards the innovative circular model would decrease the European Union's primary raw material dependency. This would benefit the European Union economically and geopolitically because large sums of capital would be saved. However, neither the Action Plan nor the other legal documentation provide guidelines and steps to integrate ports into the circular economy. The documents that are closest for establishing a legal framework for the integration of ports towards a circular economy are Directive 2008/98/EC on the prevention or reduction of the adverse effects of waste production and management and Directive 2000/59/EC on port reception facilities for ship - generated waste and cargo residues.

The integration of ports into the circular economy of the European Union can be considered of great importance because today's ports are complex industrial and logistical hubs where various value-added economic activities are carried out. The restructuring of the European Union's economy from the traditional linear model towards the innovative circular model would affect the way how ports conduct business. The aforementioned possible change in economic circumstances creates pressure on ports regarding their competitive edge because they would face economic, environmental, social and cultural changes. Ports play a significant role in the movement of the European Union's commodity flows because more than $90 \%$ of imported European goods pass through them. The 
circularity in supply chains would reduce the stated amount of imported commodity flows because the closed loop mechanism would treat waste as a secondary raw material, which would reduce the need to import primary raw materials.

The practical implication for ports with regard to their adaptation in the circular economy is therefore the focus on creating strong synergies with existing industrial clusters. They should also create and develop favorable and interesting circular economic opportunities with the aim of attracting new industries within their port cluster. The first competitive advantage in attracting new industries within their cluster would be their excellent connectivity with the waterfront and the hinterland.

The challenges of integrating ports into the circular economy would be manifested by the fact that each port is a separate individual hub within a transport network that possesses synergy with different actors. The scientific implication should be based on the analysis of ports established on the diversity of their size, function, organizational structure, geographical location and economic market position, because these criteria create different and unique strategies for their integration into the circular economy.

Future research directions should be formed on the development and implementation of the circular economy strategies by constructing renewed cooperation frameworks between the various stakeholders in the port sector. The key stakeholders would be the port authority, the harbor master's office, freight forwarding companies, industrial clusters, academic institutions and even the citizens' associations because the port is an integral part of the city. The monitoring, surveillance and development of cooperation between the various stakeholders in the port sector within the circular economy should be studied from the point of view of micro-level, meso-level and macrolevel.

\section{REFERENCES}

[1] Maletz, R., Domack, C., \& Ziyang, L. (2018). Source separation and recycling. Springer, Cham. https://doi.org/10.1007/978-3-319-69072-8

[2] Sariatli, F. (2017). Linear Economy Versus Circular Economy: A Comparative and Analyzer Study for Optimization of Economy for Sustainability. Visegrad Journal on Bioeconomy and Sustainable Development, 6(1), 31-34. https://doi.org/10.1515/vjbsd-2017-0005

[3] Ellen Mac Arthur Foundation (2013). Towards the circular economy. Cowes, UK: Ellen MacArthur Foundation

[4] Products Eurostat News (2018). EU imports and exports of raw materials up in 2018. Retrieved from https://ec.europa.eu/eurostat/web/products-eurostat-news//DDN-20190415-1

[5] European Environmental Agency (2019). Waste recycling. Retrieved from https://www.eea.europa.eu/data-andmaps/indicators/waste-recycling-1/assessment-1

[6] Circular economy in the EU. (2019).Record recycling rates and use of recycled materials in the EU. Retrieved from https://ec.europa.eu/eurostat/documents/2995521/9629294/ 8-04032019-BP-EN.pdf/295c2302-4ed1-45b9-af86$96 \mathrm{~d} 1 \mathrm{bbb} 7 \mathrm{acb} 1$

[7] Products Manuals and Guidelines. (2018). Circular Material Use Rate-Calculation Method-2018. Retrieved from: https://ec.europa.eu/eurostat/web/products-manuals-andguidelines/-/KS-GQ-18-013

[8] European Commission Framework Directive. (2019). Directive 2008/98/EC on waste (Waste Framework Directive). Retrieved from https://ec.europa. eu/environment/topics/waste-and-recycling/waste-framewo rk -directive en

[9] Circular Economy-Closing the loop. (2018). Monitoring framework for the circular economy. Retrieved from: https://ec.europa.eu/environment/circular-economy/pdf/mo nitoring-framework-factsheet.pdf

[10] EU Circular Economy Action Plan. (2015). Circular Economy Package-what's in it? Retrieved from: https://ec.europa.eu/environment/circular-economy/pdf/sem inar/1\%20DG\%20ENV Circular\%20Economy\%20package .pdf

[11] European Commission. (2020). Circular Economy Action Plan. Retrieved from https://ec.europa.eu/environment /circular-economy/

[12] Pierre, H. (2015). The EU Environmental Technology Verification (ETV) Pilot Programme.Retrieved from https://ec.europa.eu/environment/archives/ecoinnovation20 14/1st forum/presentations/day1/4-03- henry.pdf

[13]Wautelet, T. (2018). Exploring the role of independent retailers in the circular economy: a case study approach Publication No. 393538), Master's thesis, eufom European University for Economics and Management A.s.b.l.]. https://www.researchgate.net/publication/323809440_Expl oring the role of independent retailers in the circular e conomy_a_case_study_approach

[14] Weetman, C. (2017). A circular economy handbook for business and supply chains. London, UK: Kogan Page.

[15] Preston, F. (2012). A global redesign? Shaping the Circular Economy. Retrieved from https://www.chathamhouse.org/ sites/default/files/public/Research/Energy\%2C\%20Environ ment\%20and\%20Development/bp0312 preston.pdf

[16] Bastein, T., et al. (2013). Opportunities for a Circular Economy in the Netherlands. The Hague, Netherlands: The Netherlands Organisation for Applied Scientific Research.

[17] Mitchell, P. \& Morgan, J. (2015). Employment and the circular economy job creation in a more resource efficient Britain.

[18] Internal Market, Industry, Entrepreneurship and SMEs. (2017).Sustainability. Retrieved from https://ec.europa.eu/growth/industry/sustainability_en

[19] Sauvé, S., Bernard, S., \& Sloan, P. (2016). Environmental sciences, sustainable development and circular economy: Alternative concepts for trans-disciplinary research. Environmental Development, 17, 48-56. https://doi.org/10.1016/j.envdev.2015.09.002

[20] Mao, J., Li, C., Pei, Y., \& Xu, L. (2018). Circular Economy and Sustainable Development Enterprises. Singapore, Republic of Singapore: Springer Nature Singapore Pte Ltd. https://doi.org/10.1007/978-981-10-8524-6

[21] Lewandowski, M. (2016). Designing the Business Models for Circular Economy-Towards the Conceptual Framework. Sustainability, 8(1), 1-28. https://doi.org/10.3390/su8010043

[22] Ghisellini, P., Cialani, C., \& Ulgiati, S. (2016). A review on circular economy: the expected transition to a balanced interplay of environmental and economic systems. Journal of Cleaner Production, 114, 11-32. https://doi.org/10.1016/j.jclepro.2015.09.007

[23] United Nations Conference on Trade and Development. (2020). Review of Maritime Transport. Retrieved from https://unctad.org/en/PublicationsLibrary/rmt2019 en.pdf

[24] Notteboom, T. \& Winkelmans, W. (2001). Reassessing Public Sector Involvement in European Seaports. International Journal of Maritime Economics, 3(2), 242259. https://doi.org/10.1057/palgrave.jime. 9100008 
[25] Karimpour, R., Ballini, F., \& Ölcer, A. I. (2019). Circular economy approach to facilitate the transition of the port cities into self-sustainable energy ports a case study in Copenhagen-Malmö Port (CMP). WMU Journal of Maritime Affairs, 18(2), 225-247. https://doi.org/10.1007/s13437-019-00170-2

[26] Girard, L. F. (2013). Toward a Smart Sustainable Development of Port Cities/Areas: The Role of the "Historic Urban Landscape" Approach. Sustainability, 5(10), 43294348. https://doi.org/10.3390/su5104329

[27] Kyllönen, M. (2017, May 23).Can the EU's circular economy apply to ports?https://www.theparliamentmagazine.eu/ articles/opinion/can-eus-circular-economy-apply-ports

[28] Kuipers, B. (2015, May 22).Ports as catalysts for change towards a circular economy. https://www.espo.be/media /ESPO\%20Bart\%20Kuipers\%20Circular\%20Economy\%20 final $\% 202105 . p d f$

[29] Zhijun, F. \& Nailing, Y. (2007). Putting a circular economy into practice in China. Sustainability Science, 2(1), 95-101. https://doi.org/10.1007/s11625-006-0018-1

[30] Publications Office of the European Union. (2019). Accelerating the transition to the circular economy. https://op.europa.eu/en/publication-detail/-/publication/ 02590134-4548-11e9-a8ed-01aa75ed71a1/language-en/ format-PDF/source-124289088

[31] Bilitewski, B. (2012). The Circular Economy and its Risks. Waste Management,32(1), 1-2. https://doi.org/10.1016/j.wasman.2011.10.004

[32] Yuan, Z., Bi, J., \& Moriguichi, Y. (2008). The Circular Economy: A New Development Strategy in China. Journal of Industrial Ecology, 10(1-2), 4-8. https://doi.org/10.1162/108819806775545321

[33] Nederland Circular Hotspot. (2016).Your entrance to the Dutch circular economy. https://www.circleeconomy.com/archive/netherlands-circular-hotspot

[34] Rizos, V., Tuokko, K., \& Behrens, A. (2017). The Circular Economy: A review of definitions, processes and impacts. Brussels, Belgium: Centre for European Policy Studies

[35] Jonker, J., Stegeman, H., \& Faber, N. (2017). The Circular Economy-Developments, concepts, and research in search for corresponding business models. Nijmegen, The Netherlands: Radboud Universiteit Nijmegen

[36] Bergqvist, R. \& Monios, J. (Eds.). (2019). Green PortsInland and Seaside Sustainable Transportation Strategies. Amsterdam, The Netherlands: Elsevier.

[37] European Commission. (2018). EU Construction and Demolition Waste Protocol and Guidelines. Retrieved from https://ec.europa.eu/growth/content/eu-construction-anddemolition-waste-protocol-0_en

[38] European Commission. (2019).Proposal for a regulation on minimum requirements for water reuse. Retrieved from http://ec.europa.eu/ environment/water/reuse.htm

[39] European Commission. (2020).European Strategy for Plastics. Retrieved from https://ec.europa.eu/environment/ topics/plastics/si ngle-use-plastics-en

[40] The European Container Glass Federation. (2015). Glass recycling hits $73 \%$ in the EU. Retrieved from https://feve.org/glass-recycling- hits-73-eu/

[41] Yong, R. (2007). The Circular Economy in China. Journal of Material Cycles and Waste Management, 9, 121-129. https://doi.org/10.1007/s10163-007-0183-z

[42] European Sea Ports Organization. (2016). Trends in EU Ports Governance. Retrieved from https://www. espo.be/m edia/Trends in EU ports governance 2016 FINAL VER SION.pdf

[43] EUR-Lex. (2020). Directive 2019/883On port reception facilities for the delivery of waste from ships, amending Directive 2010/65/EU and repealing Directive 2000/59/EC. Retrieved from https://eur- lex.europa.eu/eli/dir/2019/883 loj

[44] Ballini, F. \& Song, D. (2017).The Role of Port Cities in Circular Economies: Cases from Europe. Retrieved from https://www.researchgate.net/publication/318363811_The Role_of_Port_Cities_in_Circular_Economies_Cases_from Europe

[45] European Federation of Inland Ports. (2016). The circular economy and inland ports. Retrieved from https://www.inlandports.eu/media/2016-04-19\%20pp\%20ci rcular\%20economy\%20-efip\%20def.pdf

\section{Contact information:}

Alen JUGOVIĆ, PhD, Professor

(Corresponding author)

University of Rijeka, Faculty of Maritime Studies,

Studentska 2, 51000 Rijeka, Croatia

E-mail: ajugovic@pfri.hr

Miljen SIROTIĆ, PhD Student

University of Rijeka, Faculty of Maritime Studies,

Studentska 2, 51000 Rijeka, Croatia

E-mail: miljensirotic@gmail.com

Dražen ŽGALJIĆ, PhD, Professor

University of Rijeka, Faculty of Maritime Studies,

Studentska 2, 51000 Rijeka, Croatia

E-mail: zgaljic@pfri.hr

Renato OBLAK, PhD

Adria Polymers d.o.o.

Poje 1, 51513 Omišalj, Croatia

E-mail: renato.oblak@ri.htnet.hr 